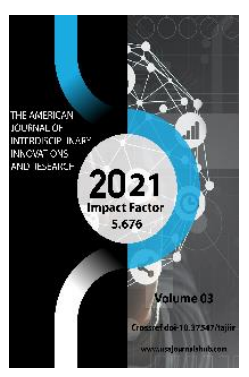

\title{
Late 19th - Early 20th Century Western Scholars Have Analyzed Data On The Climate, Nature, Flora And Fauna Of Central Asia
}

Khalilov Tulkin Zafar O'g'li

Teacher In The Middle School № 165, Tashkent, Uzbekistan

Journal Website: https://theamericanjou rnals.com/index.php/ta jiir

Copyright: Original content from this work may be used under the terms of the creative commons attributes 4.0 licence.

\section{ABSTRACT}

In the study of the history of Uzbekistan, in addition to local sources, the study of works and research by foreign authors can be used in a scientific and objective analysis of possible controversies on the subject.

The periodic boundaries of our research work cover the late 19th and early 20th centuries. During this period, a number of foreign ambassadors, traders and tourists visited Central Asia. Many of them write about their experiences here and later write about it. Such manuscripts and works also contain a wealth of impressions and information on the nature and climate of Central Asia at that time.

\section{KEYWORDS}

Uzbekistan, Central Asia, Tourist, Travel, Nature, Climate.

\section{INTRODUCTION}

Central Asia, one of the cultural centers that has made a great contribution to world civilization since ancient times, Central Asia, which at different times was part of different states, has not lost its historical significance in the world. Scholars, travelers to study the region from the outside world at different times, to study the history of the peoples who lived and lived in it, to find and study the hotbeds of ancient civilizations, the historical, geopolitical, economic and spiritual significance of this region in all periods. , ambassadors, representatives of foreign countries in the form of spies tried to enter the 
region, to find answers to all questions related to the region, to use this information for scientific and political purposes. This article contains factual information on the geography, climatic conditions, flora and fauna of Central Asia.

Climatic conditions and weather conditions have seriously affected the agricultural situation in Central Asia, especially in Bukhara. Despite the heavy rains in the spring, the high temperatures made it difficult for the plants to retain moisture. Heavy snowfall in winter and consequent river flooding in summer were farmers' dreams, as they built many canals to manage large volumes of water.

Irrigation facilities damaged by bad weather and natural disasters during the winter and spring months had to be repaired or rebuilt in the spring. Such work was carried out simultaneously throughout the country. The greatest force in such construction was the power of the people.

During the summer months, a sharp rise in temperature causes rivers across the region to fall and water levels to fall. In such cases, water distribution is carried out with the help of artificial irrigation facilities.

Ole Olufsen, a Danish tourist, commented on the region's temperature, saying that May, June, July and August are summer months for the region, with temperatures typically around 40-50 degrees Celsius, especially in July and August. On the mountain and mountain valleys, the temperature is slightly lower, for example, in the Vahan Valley in August, the temperature is around 38 degrees. In summer, the humidity in the region is $12 \%$ in May and 12 -
$14 \%$ in July and August. However, in the mountains and mountain valleys, these numbers can vary by as much as $30-35 \%$. In the summer months, the weather is so hot that the moisture in the clothes evaporates instantly, and even cigarette butts or small sparks can cause very large fires.

Ole Olufsen comments on the winter in the Emirate of Bukhara: "In winter, there are regular storms and winds from the north and northeast, and they are very strong. If this phenomenon continues until spring, it can seriously affect the quality and quantity of the crop. Winter is always a concern for the people of Bukhara. Even rich people feel the bitter cold of winter in their very poorly heated homes, and in the open air thick fur coats do not help to avoid the cold weather. Mountain valleys and their cities are almost separated from each other in winter, cold, frosty winds blow across the country, poor people and livestock often die in such cold, sometimes due to lack of food, sometimes due to cold weather. air causes. The caravans sometimes stopped on land, sometimes across the Amudarya, and the markets had almost no conditions for such cold weather. From the winter months until the arrival of spring, life in Bukhara seemed to come to a standstill, and in the spring the sun revived the life of the Emirate of Bukhara.

Spring is the beginning of life for the emirate, which has been stalled all winter. In mid-March, the mountains of the Eastern Bukhara, the valleys, and the lower reaches of the Amu Darya were flooded with spring. In the upper parts of the Pamir Mountains, such as Qoratagin, Daevesh, Roshan, Shogunan, Garan, and Vohan, the breath of spring is not 
felt until April. The plains, riverbanks, and mountain slopes of eastern Bukhara are slowly turning green, and Turkmen and Kyrgyz living in the country's border areas are gradually settling in the winter mud huts and carrying straw or reed tents. The semi-nomadic Uzbeks and Tajiks send their children and wives with their livestock to the pastures on the slopes of the mountains in early spring, where the cattle enjoy the early sunlight on the pastures and eat fresh grass. On the slopes, they lived in stone summer houses, during which time the men remained in the villages and engaged in farming and trade. It has been snowing in the upper parts of the valleys and on the mountain peaks since mid-November, and life is back to normal. In mid-May, the sounds of camels, donkeys, horses, sheep, goats, and cows could be heard from the slopes. The end of winter and the beginning of spring began with heavy rains, which took place in some areas in midFebruary. By the end of March, grapes and pomegranates have not yet shed their leaves, and some trees have already begun to shed their leaves. In March, the snow in the Eastern Bukhara hills begins to melt, but in Daran and Wahon, the snow only begins to melt in April, and eventually the snow in the Panj Valley melts. But this spring, huge granite boulders and boulders fell into the rivers below, or from the mountains, without a slogan, destroying everything in their path, and sometimes such landslides killed houses, people, and livestock. This happened several times during my stay in the Panj Valley. Many floods and mudslides occur in the rivers of eastern Bukhara in the spring. Ice movements occur in the peaks of the Panj, Kofirnihon, and Sukhrob mountains in the spring, and even in the summer it is almost impossible to cross them, and even crossing the Amudarya by boat is very dangerous. In the deep valleys of these mountains, glaciers remain for almost a year.

The sun does not radiate much heat until early April, with heavy but short rains, occasional strong hail, and lightning and thunderstorms for a short period of time in mid-April. May is already a pleasant summer in the western regions and lower mountain valleys, but May is tolerable even at 30 degrees, but by the end of May there will be almost no clouds in the sky and no wind, which is the beginning of a real summer like in North India. indicates. The region's great lakes, the Aral Sea and the Caspian Sea, contribute to climate warming when the wind blows from the northwest, and studies of valleys and plains show that the differences between them are enormous, with neither locals nor Europeans tolerating the desert. will be Rivers are usually made up of small valleys, which are irrigated by small canals in rivers, and irrigated fields and orchards also help reduce air temperature.

In summer, the population gets up early. All work is done in the morning, in the rocky morning, in June, July, August at 7-8 o'clock all wild animals and birds look for shelter and their cries are heard from shelters and bushes... In summer the locals do their best to cool down, Panj Mountain peoples living in the mountains and valleys of the Eastern Bukhara Mountains build huts on the bridges over the rivers, enjoying the coolness of the fast-flowing river during the day and at night. Small canals are dug under huge trees in gardens and valleys, and they rest on carpets or woolen shawls along these canals. In the summer, they rest outdoors on the roofs of huts or in open spaces. The hottest parts of Bukhara have less irrigated land than other areas. It is almost 
impossible to work in these places after 7 o'clock or after the temperature reaches 20 degrees, at which time people rush home and quench their thirst with warm tea. Towels soaked in water are applied to the body to protect it from heat.

As for the characteristics of autumn in the region, September is a great season for ripening grapes and watermelons, and evening walks on the cold nights of Bukhara are a special pleasure. The sound and flight of the sparrow, which disappeared from the sky during the summer months, can be seen again in the autumn. The abandoned houses of the nomads on the abandoned plains during the summer months began to fill with nomads and their livestock, and caravans of horses and camels to the area became prosperous. On the roofs of abandoned houses, women and children dry the fruit. The sun's rays slowly begin to diminish, and the pleasant autumn weather connects to the cold winter nights from November onwards.

The wind and its movement in Central Asia are important for the life of this country. The winds blowing in the region are of course strong, but the temperature in the region also depends on rainfall and evaporation. Winds blowing from the north and northeast are not saturated with moisture, they are not only dry, but also cold and have less humidity, such winds have a negative effect on the region instead of lowering the temperature. These winds are observed in the eight months of the year. In eastern Bukhara, east winds blow in summer and west winds in winter, but west winds in the Pamir valleys last all year round, and especially in the dry season, such dry, unbearable winds blowing sand from the riverbanks are a real disaster. Mountain winds, which blow regularly in all mountains, are especially strong in the evenings and sometimes cause hurricanes.

\section{CONCLUSION}

In the course of this research, after studying and analyzing the work of a number of foreign scholars, it can be said that almost all the authors of this work have written the results of their personal observations in their works. During the trip, the necessary information was obtained from the local population, and most of the travelers were able to meet with the countries and their officials, which exist in the region, albeit by name. These expeditions encountered a number of natural disasters in their expeditions and recorded these situations in their diaries. The information in their works is often the result of personal observations and surveys and interviews with local people.

\section{REFERENCES}

1. Olufsen O..The emir of Bukhara and his country. London: William Heinemann, 1911.

2. Lansdell H. Russian Central Asia. I and II vol. London: Sampson Low, 1885.

3. Curtis W.E. Turkestan: "The heart of Asia ". New York: George H.Doran company, 1911.

4. Schuyler E. Turkistan.New York: Scribner,Armstrong, 1877.

5. Wood J..A journey to the source of the river Oxus. London, 1872.

6. Huntington E. The pulse of Asia. Boston and New York: Houghton Mifflin Company, 1930. 
7. Tursunov, R. N., Bababekov, A. D., Abdullaev, I. I., \& Makhmanazarovich, K. R. (2020). THE EMERGENCE OF THE JADID MOVEMENT IN TURKESTANAND ITS RELATIONS WITH TURKEY AT THE BEGINNING OF THE XX CENTURY. Journal of Critical Reviews, 7(11), 423427.

8. Tursunov, R. N. (2019). THE RESEARCH ANALYSIS OF THE SOCIO-ECONOMIC ISSUESOF THE TURKESTAN JADIDS IN THE BEGINNING OF THE 2OTH CENTURY. Central Asian Problems of Modern Science and Education, 4(2), 337-348.

9. Tursunov, R. N. (2019). Ecological condition and mysteries in Turkestan periodical press in the early XX century (in the case of Sadoi Fergana newspaper). Theoretical \& Applied Science, (5), 570-574. 